\title{
COASTAL FLOODING: DAMAGE CLASSIFICATION AND CASE STUDIES IN CALABRIA, ITALY
}

\author{
ANTONELLA NUCERA, GIANDOMENICO FOTI, CATERINA CANALE, \\ PIERFABRIZIO PUNTORIERI \& FRANCESCA MINNITI \\ Mediterranea University of Reggio Calabria, DICEAM Department, Italy
}

\begin{abstract}
Coastal flooding is a topic of particular interest both in scientific research and for public administration. In fact, effective management of both coastal erosion and coastal flood risk requires a mapping of flooding areas by current European legislation (Directive 2007/60/EC). Regarding Italy, coastal erosion is widely studied and mapped, but coastal flooding has not been uniformly examined across all regions. This paper analyses the main factors that influence coastal flooding, being mainly tidal excursion and run-up, and a new methodology is proposed for the classification of storm damage based on the effects produced by the coastal wave action. In fact, six classes of damage have been defined, sorted by increasing severity, namely: traffic interruption, infrastructure damage, maritime works damage, erosion of beaches and dunes, flooding to homes, and a combination of these various factors. The new classification was applied to two case studies, both in Calabria (Italy): Scilla on the Tyrrhenian coast, and Monasterace on the Ionian coast. The two locations were chosen because in Scilla the coastal morphology makes it particularly subject to storms that overreach the beach and reach local houses, even those located upstream of the seafront. In Monasterace, on the other hand, there is an important archaeological site on a coastal dune that, over the years, has often been damaged by sea storms. The analysis of the events was conducted starting with data present in the A.Si.Cal. (Historically flooded areas in Calabria) of the CNR-IRPI of Cosenza, which containing data relating to events of hydrogeological instability, including sea storms which have occurred in Calabria over the last few centuries, and from the MeteoCean group of the University of Genoa, which contains wave data for the period 1979-2017, which is reconstructed from the Climate Forecast System Reanalysis (CFSR) data. Keywords: coastal flooding, coastal management, damage classes, storm, tide, run-up, set-up.
\end{abstract}

\section{INTRODUCTION}

Coastal areas represent the transition zone between sea and land [1] and are of particular importance for the presence of housing settlements. In fact, over $30 \%$ of the world [2] and the Mediterranean [3] population live a short distance from the coastline, whose economic activities are also related to tourism [4]. Coastal areas are very vulnerable under the action of both natural and anthropic factors [5], [6] which influence the shoreline evolution [7]-[10] and coastal dynamics in general.

Amongst the anthropic factors, the increase in anthropogenic pressure observed in coastal areas over the last 50 years has increased the vulnerability of the territory under the action of natural events such as floods [11], [12], storms [13], [14], coastal flooding [15]-[18], coastal erosion [19], [20], or a combination of these [21]. Furthermore, the construction of buildings, infrastructures, ports and coastal defence works [22]-[27] are of particular importance, which in most cases involve the destruction of coastal dunes [28].

Amongst the natural factors which influence coastal erosion, the sea level, the wave action [29]-[34] and the longshore and river transport [35]-[42] are of particular importance. Misdiagnosis of the factors listed above can lead to environmental disasters as in the case of Saline Joniche, near the Messina Strait [43], or in the case of Badolato, in the Calabrian Ionian coast [44]. So, for effective management of coastal areas it is of fundamental importance to know all the factors which influence the coastal dynamics [45]-[47]. 
Current European legislation, Flood Directive 2007/60/EC in fact requires the assessment of water courses and coastlines which are at risk of flooding, a mapping of the flood extent and of the assets and humans at risk in these areas, and the undertaking of adequate and coordinated measures to reduce such flood risk. It should be noted that the previous directives only took into account coastal erosion and not coastal flooding and, regarding Italy, coastal erosion was widely studied and mapped but not all regions prepared similar coastal flooding assessments. Given the above, the classification of damage produced by coastal flooding is of particular importance in order to map flooding areas.

The paper proposes a new methodology for classifying the damage produced by coastal flooding. The methodology was applied in two case studies, both in Calabria (Italy), being for Scilla, on the Tyrrhenian coast, and Monasterace, on the Ionian coast. The two towns were chosen because in Scilla the coastal morphology makes it particularly subject to storms that overstep the beach and reach the local houses, including those located upstream from the seafront. In Monasterace, on the other hand, there is an important archaeological site on a coastal dune that, over the years, has often been damaged by sea storms.

\section{METHODOLOGY}

The definition of the new damage classification methodology was preceded by an analysis of the storms that affected the two locations studied. This analysis was conducted using data present in two databases. The first was the A.Si.Cal. (Historically flooded areas in Calabria) of the CNR-IRPI of Cosenza, containing events of hydrogeological instability, including sea storms which occurred in Calabria in the last few centuries. For each event it was possible to identify the date of the event and its effect. The second database is from the MeteoCean group of the University of Genoa and contains wave data for the period 1979-2017, reconstructed from the Climate Forecast System Reanalysis (CFSR) database. From this data, Boccotti's theory [48] was used to identify storms. In particular, by obtaining the critical height as being 1.5 times the mean of the significant heights recorded for the whole time series, it was possible to identify the events during which this threshold was exceeded. Of all the identified storms, only those present in the A.Si.Cal. database which caused damage were examined, and for each of these the maximum significant wave height and the storm duration were estimated.

The new methodology for classification of the damage caused by storms is based on the effects produced by the wave action on the coast. In fact, six classes of damage, sorted by increasing severity, have been defined as follows:

1. Traffic interruption;

2. Infrastructure damage;

3. Maritime works damage;

4. Erosion of beaches and dunes;

5. Flooding to homes;

6. Combination of these factors.

For both locations, coastal flooding hazard maps were also drawn up for 3 different scenarios, corresponding to storms with a return period of 1,10 and 50 years respectively. The maps were plotted by comparing the elevations, obtained from the cartographic data available in the Calabrian geoportal, with the run-up values reached by the storms, inclusive of the tidal excursion. These excursions were estimated starting from the data recorded by the gauges of the National Tidal Network. In neither location are there any gauges therefore the nearest station data was analyzed, being Reggio Calabria for Scilla and Crotone for 
Monasterace. Over 350,000 data items are available across both locations. The run-up values were estimated using the formulas of Mase [49], Nielsen and Hanslow [50], Mangor [51], and Stockdon et al. [52].

\section{CASE STUDIES}

The first case study is related to Scilla, a town located near the Strait of Messina, in a territory compressed between sea and mountain and often subject to phenomena of hydrogeological instability, which include storms that overstep the beach and reach the houses, even those

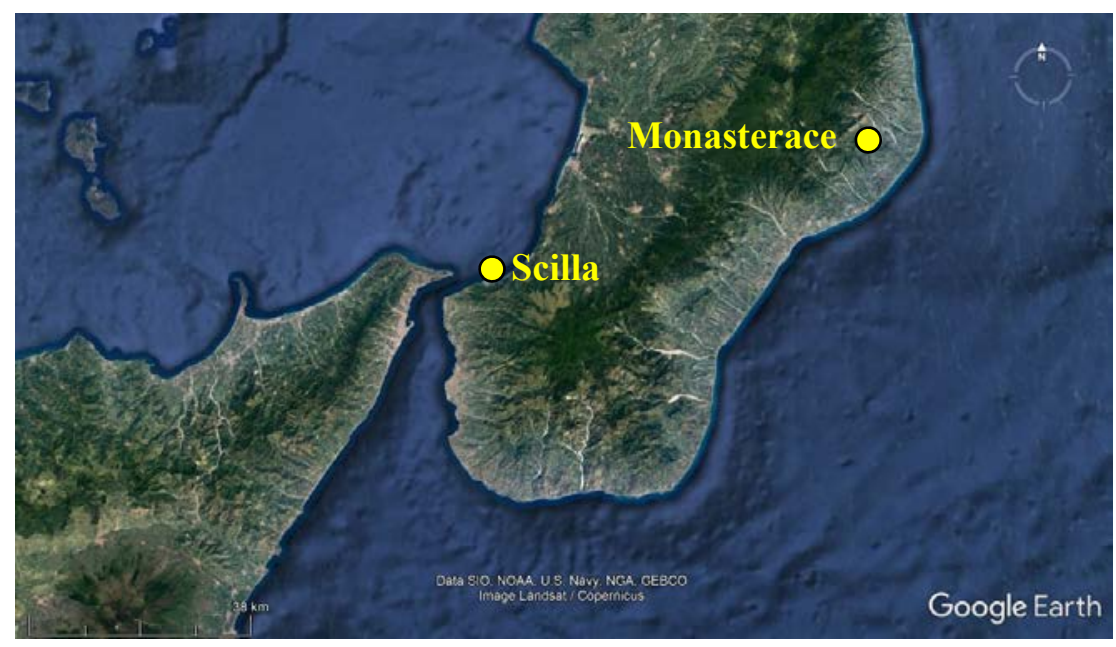

Figure 1: Location of Scilla and Monasterace.

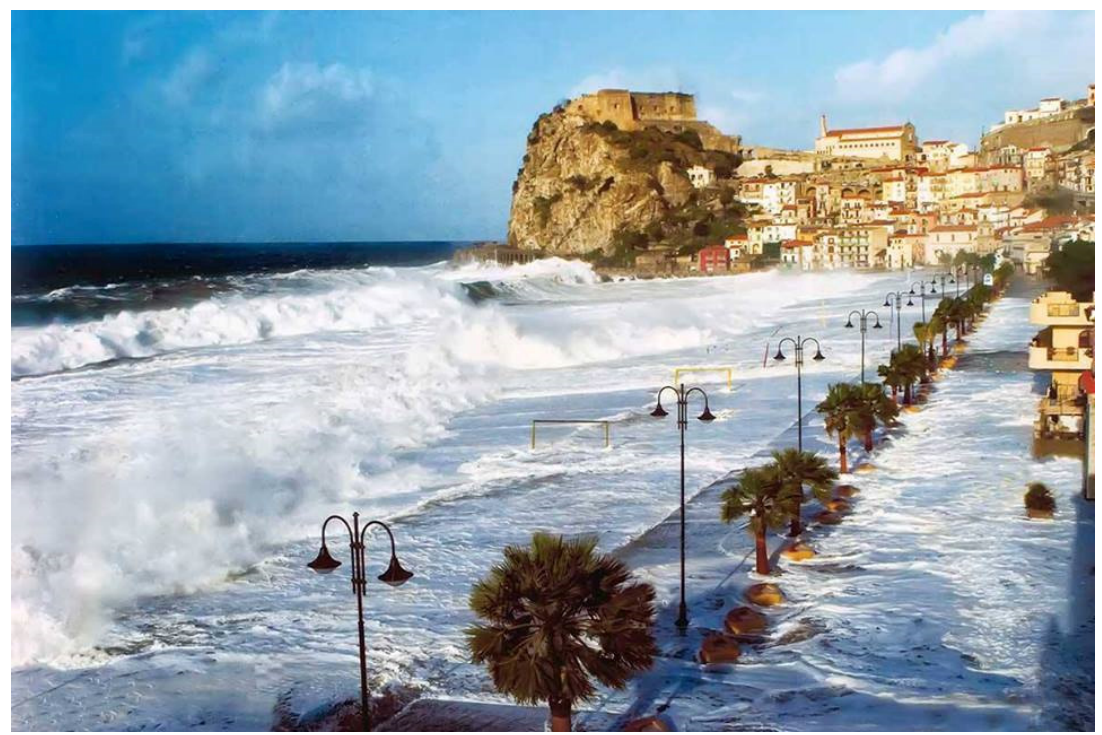

Figure 2: Coastal flooding in Scilla. 

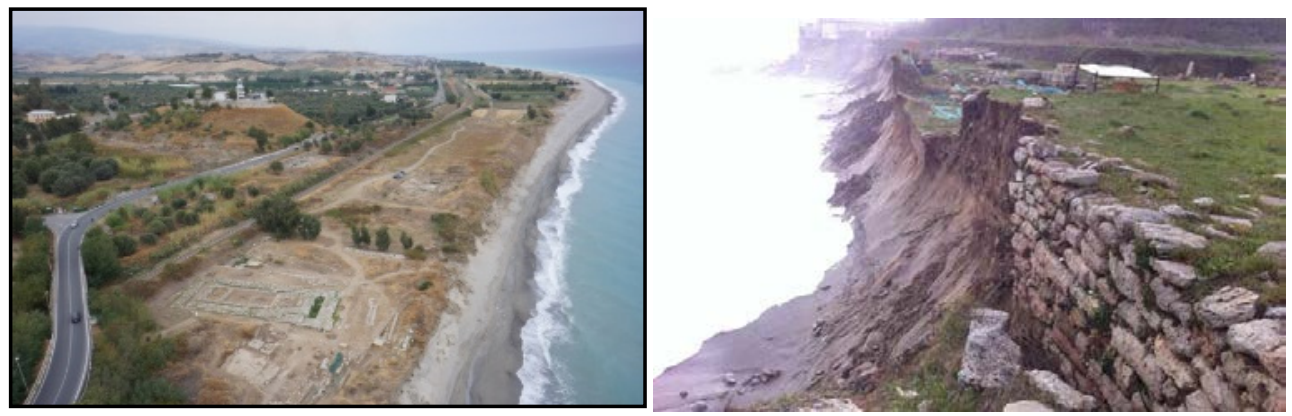

Figure 3: On the left: archaeological site near Monasterace. On the right: coastal flooding.

located upstream of the seafront. The second case study is related to Monasterace, a town located on the Ionian coast of Calabria. Near the town there is an important archaeological site on a coastal dune that has often been damaged by sea storms over the years.

From the two databases described above, 20 events were identified for Scilla and 11 for Monasterace, excluding events for which the information on the type of damage was not available. For each event, the damage produced was classified with the new methodology.
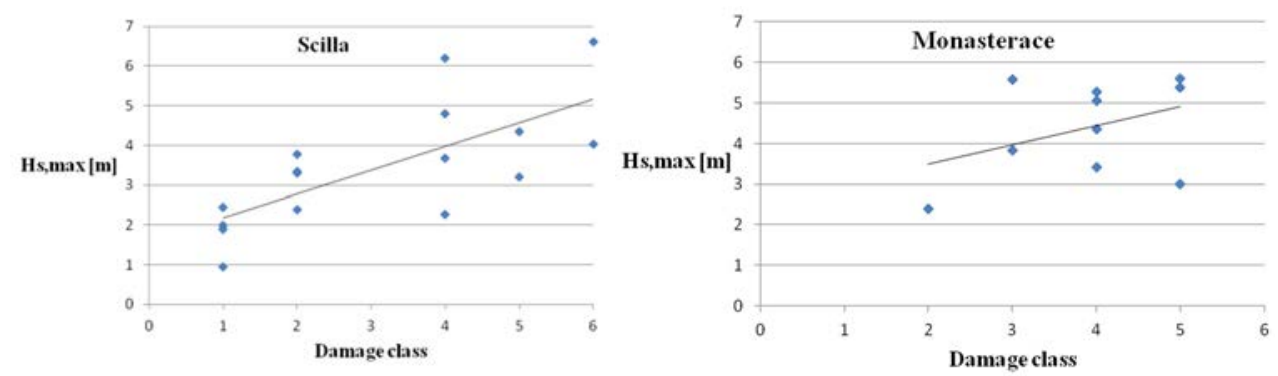

Figure 4: Correlation between the damage class and the maximum significant wave height for Scilla (on the left) and Monasterace (on the right).
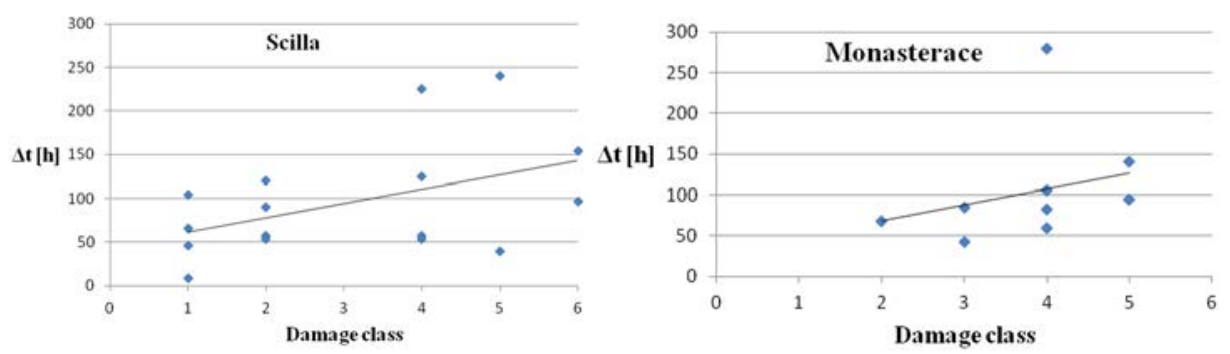

Figure 5: Correlation between the damage class and the storm duration for Scilla (on the left) and Monasterace (on the right). 
Subsequently, the correlations between the damage class and the maximum significant wave height of the storm and between the damage class and the storm duration were analysed. The results obtained are shown in the graphs below.

From the analysis of the results shown in the previous figures it is possible to observe that damage levels increase with increasing significant wave height and storm duration.

Regarding the coastal flooding hazard maps, as previously described, the tidal excursions and the run-up values of both locations were preliminarily estimated. In particular, the tidal excursion obtained at Scilla is greater than $20 \mathrm{~cm}$ while the variation at Monasterace is slightly less than $50 \mathrm{~cm}$. In both cases these are low values, but still in line with the results obtained by Sannino et al. [53]. Regarding the run-up values, the results provided by the various expressions were compared with the events in the A.Si.Cal. database to identify the most representative expressions for each location. These expressions are Mase for Scilla and Nielsen and Hanslow for Monasterace. In particular, in Scilla the run-up value is about $4 \mathrm{~m}$, $6 \mathrm{~m}$ and $7.5 \mathrm{~m}$ for return periods of 1,10 and 50 years respectively. In Monasterace, on the other hand, the run-up value is about $3 \mathrm{~m}, 4.5 \mathrm{~m}$ and $5.5 \mathrm{~m}$ for the same return periods. The figures below show the maps of both locations.

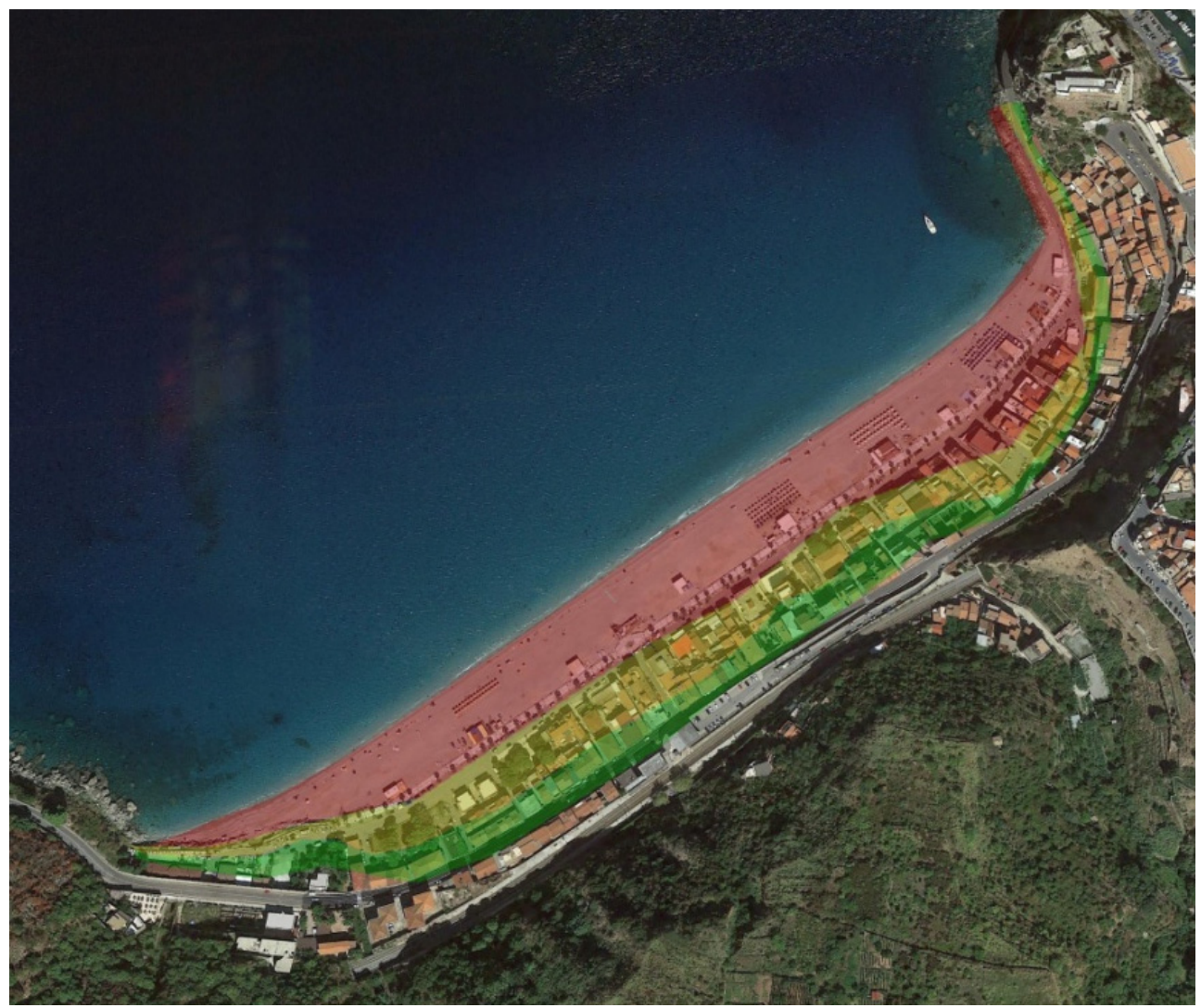

Figure 6: Coastal flooding hazard map of Scilla. (Legend: red = return period of 1 year, yellow $=$ return period of 10 years, green $=$ return period of 50 years.) 


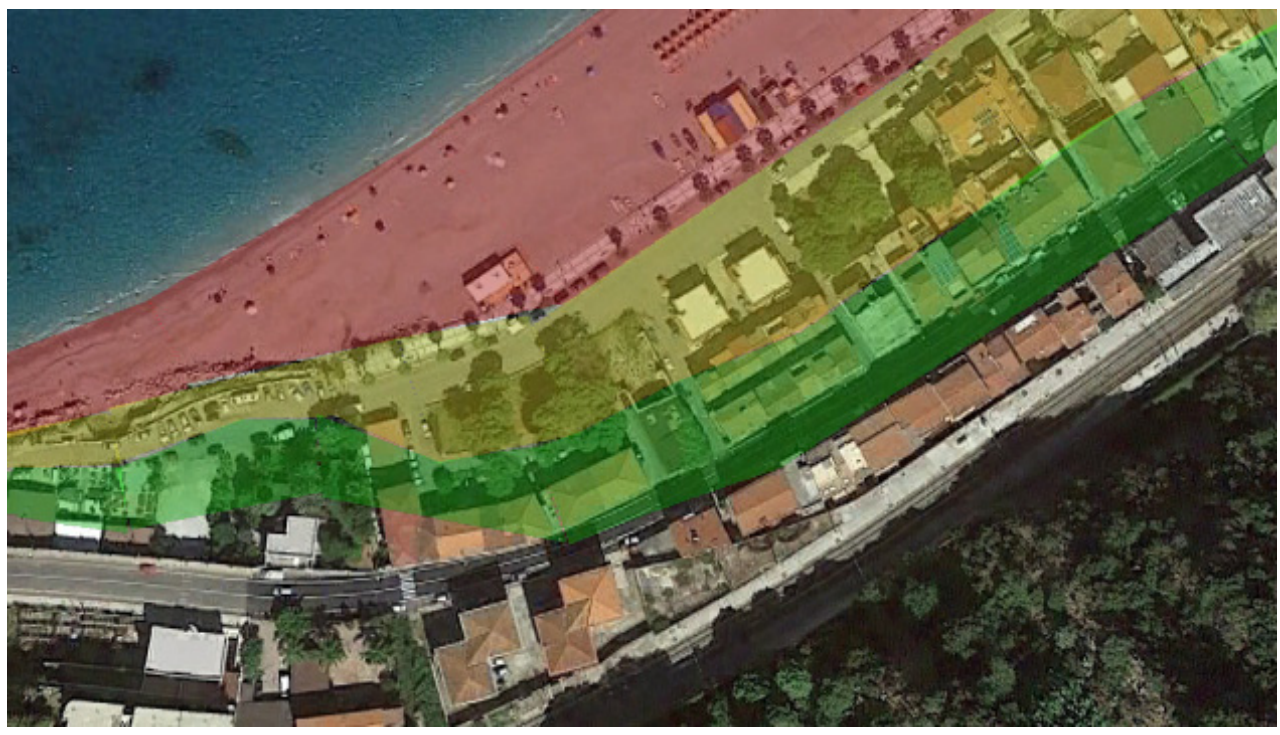

Figure 7: Detail of coastal flooding hazard map of Scilla. (Legend: red = return period of 1 year, yellow $=$ return period of 10 years, green $=$ return period of 50 years.)

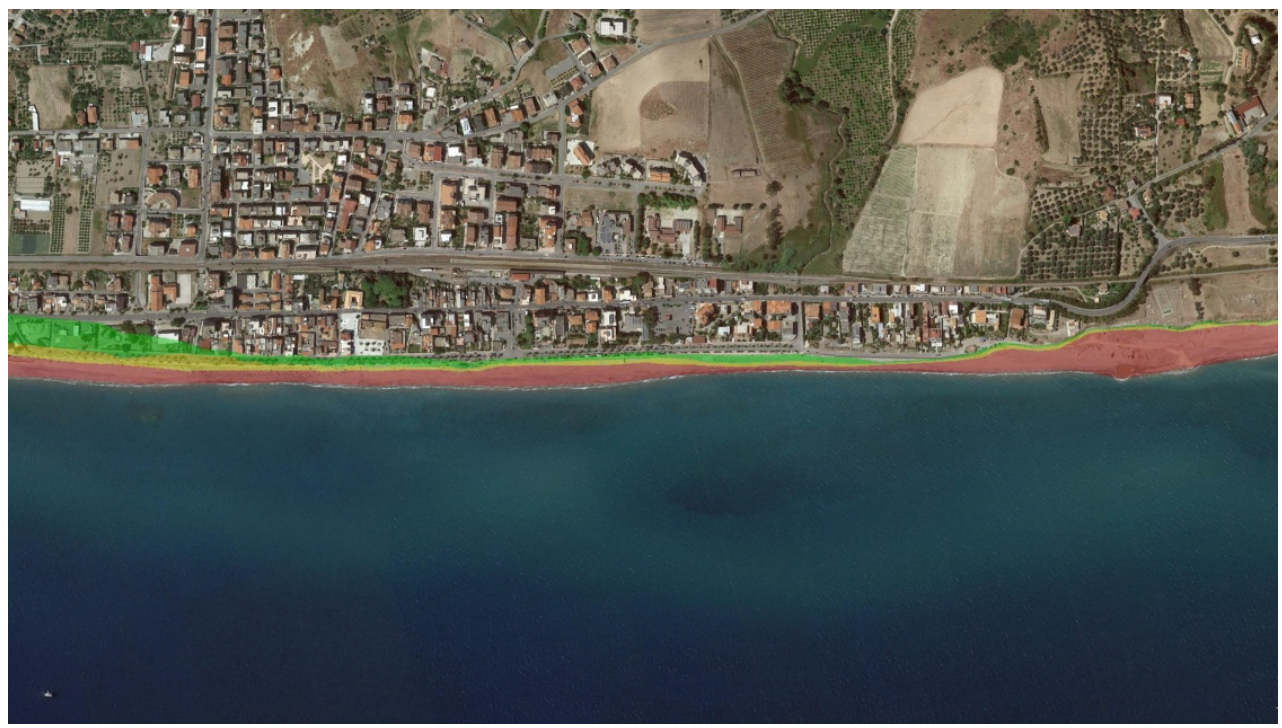

Figure 8: Coastal flooding hazard map of Monasterace. (Legend: red = return period of 1 year, yellow $=$ return period of 10 years, green $=$ return period of 50 years.) 


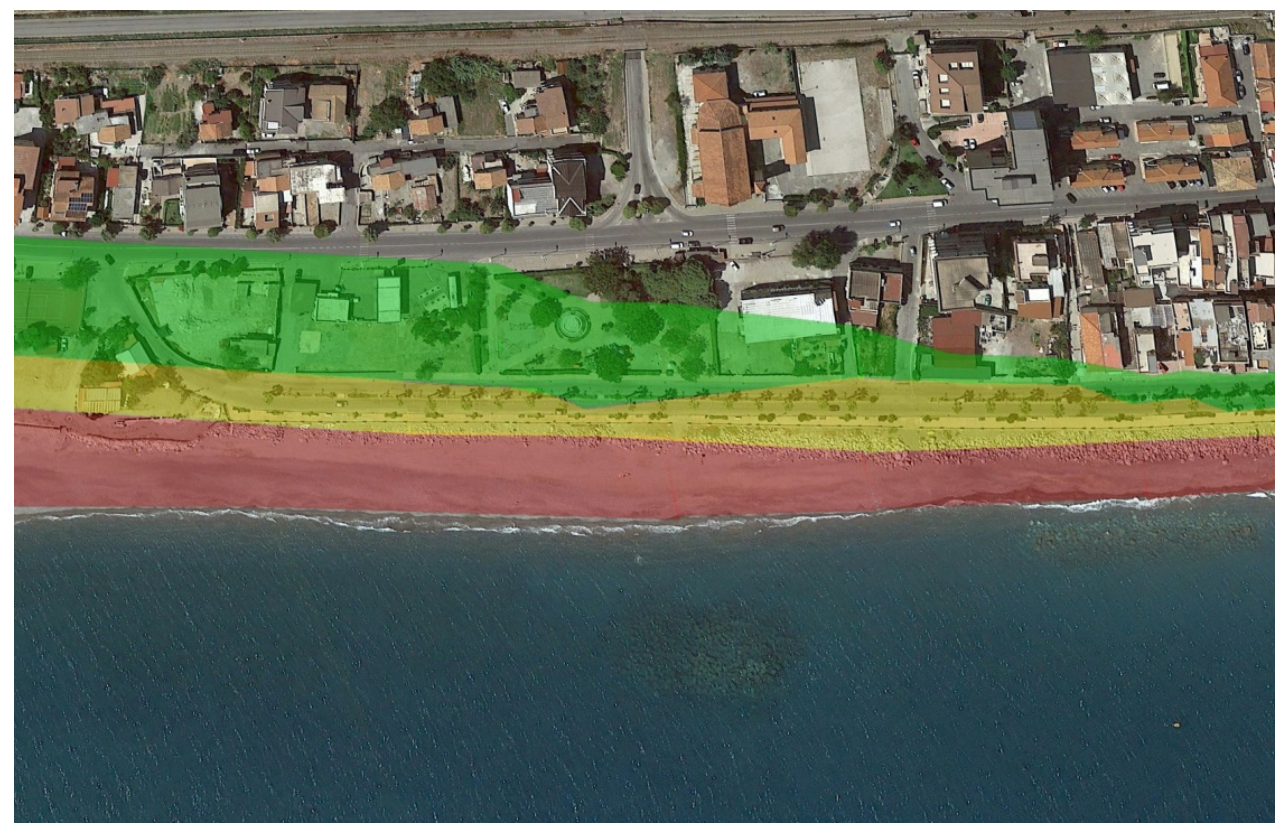

Figure 9: Detail of coastal flooding hazard map of Monasterace. (Legend: red = return period of 1 year, yellow $=$ return period of 10 years, green $=$ return period of 50 years.)

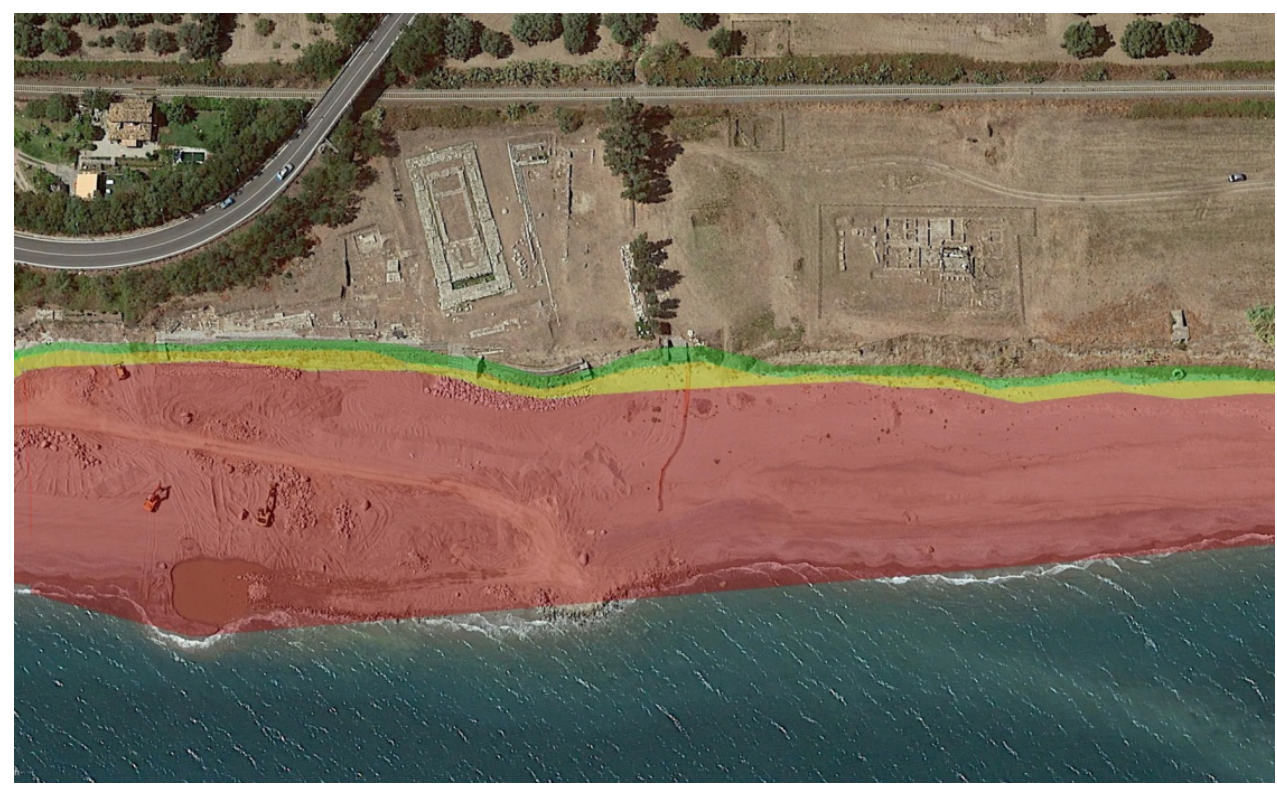

Figure 10: Detail of coastal flooding hazard map of Monasterace, near the archaeological site. (Legend: red $=$ return period of 1 year, yellow $=$ return period of 10 years, green $=$ return period of 50 years.) 


\section{CONCLUSIONS}

The paper analysed the main factors which influence coastal flooding, being mainly tidal excursion and run-up, and proposed a new methodology for classifying the damage produced by coastal flooding. The new methodology is based on the effects produced by the wave action on the coast. In fact, six categories of damage, sorted by increasing severity, have been defined as follows:

1. Interruption of traffic;

2. Damage to infrastructure;

3. Damage to maritime works;

4. Erosion of beaches and dunes;

5. Flooding to homes;

6. Combination of these factors.

The new methodology has been also applied to two case studies, both in Calabria (Italy): Scilla, on the Tyrrhenian coast, and Monasterace, on the Ionian coast. The two towns were chosen because in Scilla the coastal morphology makes it particularly subject to storms that overstep the beach and reach the houses, even those located upstream of the seafront. In Monasterace, on the other hand, there is an important archaeological site on a coastal dune that, over the years, has often undergone sea storm damage.

For both locations, previously occurring storms were analysed. This analysis was conducted starting with the data present in two databases. The first of them was the A.Si.Cal. (Historically flooded areas in Calabria) of the CNR-IRPI of Cosenza, containing events of hydrogeological instability (including sea storms) which occurred in Calabria in the last centuries. For each event it was possible to identify the date of the event and its effect. The second database is from the MeteoCean group of the University of Genoa which contains wave data for the period 1979-2017, reconstructed from data from the Climate Forecast System Reanalysis (CFSR). From this data, Boccotti's theory was used to identify storms. Of all the identified storms, only those present in the A.Si.Cal. database, which caused damage, were examined and for each of them the maximum significant wave height and the storm duration were estimated. For each event, the damage produced was classified using the new methodology. Following this, the correlations between the damage class and the maximum significant wave height of the storm and between the damage class and the storm duration were analysed and it was possible to observe that the damage level grew with the increase in significant wave height and storm duration.

In addition, for both locations, coastal flooding hazard maps were also drawn up for 3 different scenarios, corresponding to storms with a return period of 1, 10 and 50 years. The maps were plotted by comparing the elevation obtained from the cartographic data available in the Calabrian geoportal with the run-up values reached by the storms, inclusive of the tidal excursion.

Currently, coastal flooding is a topic of particular interest both in scientific research and for public administration. In fact, for effective coastal management it is necessary to examine both coastal erosion and coastal flood risk, as required by current European legislation (Directive 2007/60/EC), in order to map flooding areas. Regarding Italy, coastal erosion is widely studied and mapped but coastal flooding has not been examined equally across all regions. In conclusion, the proposed new methodology could significantly improve coastal management. 


\section{REFERENCES}

[1] Boak, E.H. \& Turner, I.L., Shoreline definition and detection: a review. Journal of Coastal Research, 21(4), pp. 688-703, 2005.

[2] Syvitski, J.P.M., Vorosmarty, C.J., Kettner, A.J. \& Green, P., Impact of humans on the flux of terrestrial sediment to the global coastal ocean. Science, 308(5720), pp. 376380, 2005.

[3] European Union, Sustainable tourism in the Mediterranean. Report, 2012.

[4] Lanquar, R., Tourism in the Mediterranean: Scenarios up to 2030. MEDPRO report No.1, 2011.

[5] Marin, V., Palmisani, F., Ivaldi, R., Dursi, R. \& Fabiano, M., Users' perception analysis for sustainable beach management in Italy. Ocean and Coastal Management, 52(5), pp. 268-277, 2009.

[6] Manca, E., Pascucci, V., Deluca, M., Cossu, A. \& Andreucci, S., Shoreline evolution related to coastal development of a managed beach in Alghero, Sardinia, Italy. Ocean and Coastal Management, 85, pp. 65-76, 2013.

[7] Pilkey, O.H. \& Hume, T., The shoreline erosion problem: lessons from the past. Water \& Atmosphere, 9(2), pp. 22-23, 2001.

[8] Maiti, S. \& Bhattacharya, A.K., Shoreline change analysis and its application to prediction: A remote sensing and statistics-based approach. Marine Geology, 257(14), pp. 11-23, 2009.

[9] Addo, K.A., Shoreline morphological changes and the human factor. Case study of Accra Ghana. Journal of Coastal Conservation, 17(1), pp. 85-91, 2013.

[10] Barbaro, G., Fiamma, V., Barrile, V., Foti, G. \& Ielo, G., Analysis of the shoreline changes of Reggio Calabria (Italy). International Journal of Civil Engineering and Technology, 8(10), pp. 1777-1791, 2017.

[11] Fiori, E. et al., Analysis and hindcast simulations of an extreme rainfall event in the Mediterranean area: The Genoa 2011 case. Atmospheric Research, 138, pp. 13-29, 2014.

[12] Scionti, F., Miguez, M.G., Barbaro, G., De Sousa, M.M., Foti, G. \& Canale, C., An integrated methodology for urban flood risk mitigation: the case study of Cittanova (Italy). Journal of Water Resources Planning and Management, in press.

[13] Arena, F., Barbaro, G. \& Romolo, A., Return period of a sea storm with at least two waves higher than a fixed threshold. Mathematical Problems in Engineering, pp. 1-6, 2013.

[14] Boudet, L., Sabatier, F. \& Radakovitch, O., Modelling of sediment transport pattern in the mouth of the Rhone delta: Role of storm and flood events. Estuarine, Coastal and Shelf Science, 198, pp. 568-582, 2017.

[15] Martinez-Grana, A.M., Boski, T., Goy, J.L., Zazo, C. \& Dabrio, C.J., Coastal-flood risk management in central Algarve: Vulnerability and flood risk indices (South Portugal). Ecological Indicators, 71, pp. 302-316, 2016.

[16] Ferreira Silva, S., Martinho, M., Capitao, R., Reis, T., Fortes, C.J. \& Ferreira, J.C., An index-based method for coastal-flood risk assessment in low-lying areas (Costa de Caparica, Portugal). Ocean \& Coastal Management, 144, pp. 90-104, 2017.

[17] Li, N., Yamazaki, Y., Roeber, V., Cheung, K.F. \& Chock, G., Probabilistic mapping of storm-induced coastal inundation for climate change adaption. Coastal Engineering, 133, pp. 126-141, 2018.

[18] Lemee, C. et al., Factorial structure of the coastal flooding risk perception and validation of a French coastal flooding risk evaluation scale (CFRES) for non-experts. Ocean \& Coastal Management, 155, pp. 68-75, 2018. 
[19] Komar, P.D., Coastal erosion-underlying factors and human impacts. Shore \& Beach, 68(1), pp. 3-16, 2000.

[20] Barbaro, G., Foti, G. \& Sicilia, C.L., Coastal erosion in the South of Italy. Disaster Advances, 7, pp. 37-42, 2014.

[21] Barbaro G., Petrucci O., Canale C., Foti G., Mancuso P. \& Puntorieri P., Contemporaneity of floods and storms. A case study of Metropolitan Area of Reggio Calabria in Southern Italy. Prooceedings of New Metropolitan Perspectives (NMP), Reggio Calabria, Italy, 2018.

[22] Barbaro, G., A new expression for the direct calculation of the maximum wave force on vertical cylinders. Ocean Engineering, 34, pp. 1706-1710, 2007.

[23] Barbaro, G., Estimating design wave for offshore structures in Italian waters. Proceedings of the Institution of Civil Engineering, Maritime Engineering, 164, pp. 115-125, 2011.

[24] Barbaro, G. \& Foti, G., Shoreline behind a breakwater for wave energy absorption in Reggio Calabria: comparison between theoretical models and experimental data. Proceedings of 2nd International Conference on Physical Coastal Processes, Management and Engineering, Naples, Italy, pp. 237-248, 2011.

[25] Barbaro, G. \& Foti, G., Shoreline behind a breakwater: comparison between theoretical models and field measurements for the Reggio Calabria sea. Journal of Coastal Research, 29, pp. 216-224, 2013.

[26] Barbaro, G., Foti, G. \& Sicilia, C.L., Wave forces on upright breakwater, evaluation and case study. Disaster Advances, 6, pp. 90-95, 2013.

[27] Barbaro, G., Foti, G. \& Sicilia, C.L., Evaluation of the horizontal wave forces on piles. Journal of Air, Soil and Water Research, 7, pp. 103-110, 2014.

[28] Tomasicchio, G.R., D’Alessandro, F. \& Barbaro, G., Composite modelling for largescale experiments on wave-dune interaction. Journal of Hydraulic Research, 49, pp. 15-19, 2011.

[29] Rahman, A.F., Dragoni, D. \& El-Masri, B., Response of the Sundarbans coastline to sea level rise and decreased sediment flow: a remote sensing assessment. Remote Sensing of Environment, 115(12), pp. 3121-3128, 2011.

[30] Boccotti, P., Arena, F., Fiamma, V., Romolo, A. \& Barbaro, G., Estimation of mean spectral directions in random seas. Ocean Engineering, 38, pp. 509-518, 2011.

[31] Barbaro, G., Foti, G. \& Malara, G., Set-up due to random waves: influence of the directional spectrum. Proceedings of 30th International Conference on Ocean, Offshore and Artic Engineering OMAE, Rotterdam, The Netherlands, 2011.

[32] Barbaro, G., Foti, G. \& Malara, G., Set-up due to random waves: influence of the directional spectrum. International Journal of Maritime Engineering, 155, pp. A105A115, 2013.

[33] Barbaro, G., Foti, G. \& Sicilia, C.L., Maximum wave forces: evaluation and case studies. Proceedings of 32nd International Conference on Ocean, Offshore and Artic Engineering OMAE, Nantes, France, 2013.

[34] Barbaro, G., Gangemi, M.D. \& Foti, G., An agent-based tsunami alert system. Proceedings of 18th Workshop "From Objects to Agents” WOA, Scilla Italy, 2017.

[35] Barbaro, G., Foti, G., Mandaglio G., Mandaglio, M. \& Sicilia, C.L., Estimate of sediment transport capacity in the basin of the Fiumara Annunziata (RC). Rendiconti Online Società Geologica Italiana, 21(1), pp. 696-697, 2012.

[36] Sicilia, C.L., Foti, G. \& Campolo, A., Protection and management of the Annunziata river mouth area (Italy). Journal of Air, Soil and Water Research, 6, pp. 107-113, 2013. 
[37] Tomasicchio, G.R., D’Alessandro, F., Barbaro, G. \& Malara, G., General longshore transport model. Coastal Engineering, 71, pp. 28-36, 2013.

[38] Barbaro, G., Foti, G., Sicilia, C.L. \& Malara, G., A formula for the calculation of the longshore sediment transport including spectral effects. Journal of Coastal Research, 30, pp. 961-966, 2014.

[39] Zema, D.A., Bombino, G., Boix-Fayos, C., Tamburino, V., Zimbone, S.M. \& Fortugno, D., Evaluation and modeling of scouring and sedimentation around check dams in a Mediterranean torrent in Calabria, Italy. Journal of Soil and Water Conservation, 69(4), 316-329, 2014.

[40] Tomasicchio, G.R., D’Alessandro, F., Barbaro, G., Musci, E. \& De Giosa, T.M., Longshore transport at shingle beaches: an independent verification of the general model. Coastal Engineering, 104, pp. 69-75, 2015.

[41] Yang, Z., Wang, T., Voisin, N. \& Copping, A., Estuarine response to river flow and sea-level rise under future climate change and human development. Estuarine, Coastal and Shelf Science, 156, pp. 19-30, 2015.

[42] Borrello, M.M., Foti, G. \& Puntorieri, P., Shoreline evolution near the mouth of the Petrace River (Reggio Calabria, Italy). Proceedings of 9th International Conference on River Basin Management, Prague, Czech Republic, 2017.

[43] Barbaro, G., Saline Joniche: a predicted disaster. Disaster Advances, 6, pp. 1-3, 2013.

[44] Miduri, M., Foti, G. \& Puntorieri, P., Impact generated by Marina of Badolato (Italy) on adjacent coast. Proceedings of 13th International Congress on Coastal and Marine Sciences, Engineering, Management and Conservation MEDCOAST, Mellieha, Malta, 2017.

[45] Foti, G. \& Sicilia, C.L., Analysis, evaluation and innovative methodologies to prevent coastal erosion. Proceedings of 3rd International Conference on Physical Coastal Processes, Management and Engineering, Gran Canaria, Spain, 2013.

[46] Barbaro, G., Master Plan of solutions to mitigate the risk of coastal erosion in Calabria (Italy), a case study. Ocean \& Coastal Management, 132, pp. 24-35, 2016.

[47] Poeta, G., Conti, L., Malavasi, M., Battisti, C. \& Acosta, A.T.R., Beach litter occurrence in sandy littorals: The potential role of urban areas, rivers and beach users in central Italy. Estuarine, Coastal and Shelf Science, 181, pp. 231-237, 2016.

[48] Boccotti, P., Wave Mechanics and Wave Loads on Marine Structures, Elsevier BH: Oxford, UK, 2015.

[49] Mase, H., Random wave runup height on gentle slope. Journal of Waterway, Port, Coastal and Ocean Engineering, 115(5), pp. 649-661, 1989.

[50] Nielsen, P. \& Hanslow, D.J., Wave runup distributions on natural beaches. Journal of Coastal Research, 7(4), pp. 1139-1152, 1991.

[51] Mangor, K., Shoreline Management Guidelines, DHI Water \& Environment: Horsholm, Denmark, 2004.

[52] Stockdon, H.F., Holman, R.A., Howd, P.A. \& Sallenger, A.H.J., Empirical parameterization of setup, swash, and runup. Coastal Engineering, 53(7), pp. 573-588, 2006.

[53] Sannino, G., Carillo, A., Pisacane, G. \& Naranjo, C., On the relevance of tidal forcing in modeling the Mediterranean thermohailine circulation. Progress in Oceanography, 134, pp. 304-329, 2015. 